MÁRIO CHIUVITE JÚNIOR

PROCESSO E JUSTIÇA:

\title{
UMA REFLEXÃO À LUZ DOS IDEAIS ÉTICOS FUNDAMENTAIS NO ÂMBITO DA PACIFICAÇÃO DOS CONFLITOS JUDICIAIS
}

TESE DE DOUTORADO

PROFESSOR ORIENTADOR: DR. ARI MARCELO SOLON

FACULDADE DE DIREITO DA UNIVERSIDADE DE SÃO PAULO SÃO PAULO 
MÁRIO CHIUVITE JÚNIOR

PROCESSO E JUSTIÇA:

UMA REFLEXÃO À LUZ DOS IDEAIS ÉTICOS FUNDAMENTAIS NO

ÂMBITO DA PACIFICAÇÃO

DOS CONFLITOS JUDICIAIS

Tese apresentada ao Programa de Pós-Graduação da Faculdade de Direito da Universidade de São Paulo, como requisito parcial para a obtenção do título de Doutor em Direito (Filosofia e Teoria Geral do Direito), sob a orientação do Professor Doutor Ari Marcelo Solon.

SÃO PAULO 
Banca Examinado ra 


\section{AGRADECIMENTOS}

Aos meus queridos pais, in memoriam, por todos os princípios de vida a mim passados.

À minha querida esposa, por todo o carinho e dedicação, demonstrados durante a nossa vida e elaboração desta tese.

Ao meu querido filho, pela alegria incessante de viver, que me é passada a cada momento de minha vida.

Ao meu orientador, sinceros agradecimentos, por toda a atenção a mim dispensada durante a elaboração deste trabalho. 


\section{RESUMO}

Neste estudo, são estabelecidas premissas de um processo verdadeiramente ético, mais justo, tendo em vista a concepção do entendimento ético à luz de Sócrates, Platão, Kant e, sobretudo, Aristóteles, no sentido de se conceber uma noção de ética aplicável à nossa realidade, principalmente à atualidade do processo. Busca-se a ideia de justiça em cotejo com a questão do andamento dos processos, das formas de solução de conflitos e do modo de atuação do juiz no âmbito do trâmite processual. Deve haver a observância efetiva da ética e da justiça no processo, com vistas à sua celeridade, ao alcance da efetiva igualdade substancial entre as partes, com a expressão do seu tratamento justo e igual, aparando-se eventuais injustiças verificadas no bojo do processo, evitando-se o excesso de trâmite processual, com a redução racional de meios processuais e recursais utilizados de modo desnecessário e desproporcional. Em tal contexto, também se deve buscar o exame justo e ético do processo, sob a ótica da atuação do magistrado, evidenciando-se uma maneira ética de atuação do juiz na condução do processo. Assim sendo, propugna-se pela análise do objeto processual com vistas à extensão social da decisão judiciária proferida, seus aspectos coletivos e a manutenção integral e incondicional do Estado Democrático de Direito e da efetivação dos direitos fundamentais (humanos), mencionando-se que nesta tese avaliamos o processo em sua dinâmica geral, na esfera de sua Teoria Geral, a fim sempre de se alcançar a plena efetividade, eficácia, justiça e ética processual como forma de alterar a atual realidade forense, que não atende às crescentes exigências oriundas da explosão atual de demandas sociais. 


\begin{abstract}
This work establishes the premises of a truly and fair process, considering the ethical conception of Socrates, Plato, Kant and above all, Aristotle, to conceive an ethical notion that may fit to our reality. It pursuit the idea of justice comparing the issue of proceedings, conflicts resolution and the judge's behavior in the proceedings. With the intention of reach the equality between the parts, reduce not only some unfair act that may exist in the process but proceeding means used disproportionally and unnecessarily too, the search for a proceed that be ethical and fair is fundamental. Therefore, the magistrate judgment shall intent an ethical way of process conduction. It struggles for the process object analysis regarding the social span of sentence, its collective aspects and the unconditional preservation of the Democratic State of Law and basics human rights standings. There is, in the present study, an evaluation of the whole process dynamic within the General Theory of State aiming to modify the present condition of rising social demands to a high level of effectiveness, efficacy, justice and procedural ethics.
\end{abstract}




\section{SUMÁRIO}

INTRODUÇÃO

1 A ÉTICA: CONCEPÇÕES FUNDAMENTAIS.......................................... 5

1.1 Noções gerais acerca da ética, segundo Sócrates..................................... 9

$1.2 \quad$ A visão ética de Platão........................................................................... 12

$1.3 \quad$ A visão ética de Aristóteles.................................................................... 14

$1.4 \quad$ A visão ética de Immanuel Kant............................................................ 19

2 A VISÃO DE JUSTIÇA DE ARISTÓTELES: UMA CONCEPÇÃO FULCRADA NOS LIVROS V E VI DA OBRA ÉTICA A NICÔMACO

3 A NOÇÃO DE PROCESSO NO BOJO DE SUA TEORIA GERAL, O CONTEXTO ATUAL DO PODER JUDICIÁRIO E O PAPEL ÉTICO DO JUIZ NO PROCESSO

4 O ACESSO À JUSTIÇA VISUALIZADO COMO UM DIREITO HUMANO FUNDAMENTAL. TAL AFERIÇÃO POSTA EM UMA SITUAÇÃO DE PROBLEMATIZAÇÃO DO FENÔMENO DA PRESTAÇÃO JURISDICIONAL: O CAMINHO PARA SE PROPUGNAR POR UM PROCESSO IDEALMENTE ÉTICO NA ACEPÇÃO DEFENDIDA POR ARISTÓTELES.

CONCLUSÃO

BIBLIOGRAFIA 